\title{
Accumulation of cadmium by halophyte species Juncus gerardii Loisel
}

\author{
*Radka Podlipná, **Kateřina Mot’ková, *Tomáš Vaněk \\ *Laboratory of Plant Biotechnologies, Joint Laboratory of Institute of Experimental \\ Botany AS CR, v.v.i. and Research Institute of Crop Production, v.v.i., \\ Rozvojová 263, 16502 Prague 6, Czech Republic \\ e-mail: podlipna@ueb.cas.cz \\ **Faculty of Environmental Technology, Institute of Chemical Technology, \\ Technická 5, 16628 Prague 6, Czech Republic
}

Summary. In our experiments, we observed the accumulation of $\mathrm{Cd}^{2+}$ by in vitro cultured Juncus species cultivated on medium with $100 \mu \mathrm{M} \mathrm{Cd}$ and without or with $\mathrm{NaCl}(300$ and $900 \mu \mathrm{M})$ for 7 days. The content of $\mathrm{Cd}^{2+}$ in plants cultivated on medium without $\mathrm{NaCl}$ continuously increased. On the other hand, in the presence of $\mathrm{NaCl}$, the plants accumulated the highest amount of $\mathrm{Cd}^{2+}$ during first 24 hours and then the accumulation decreased.

Key words: phytoremediation, Juncus gerardii, Juncus inflexus, cadmium.

\section{Introduction}

Phytoremediation is a low invasive, alternative cleaning method, which use plants and their associated microorganisms to accumulate selected contaminants from soil, sludge, sediment, ground water, surface water, and wastewater (Cunningham et al. 1996). Heavy metal contamination of soil and ground water causes major environmental and human health problems. This contamination also concerns arid zones with saline soils. With the aim to use the phytoremediation techniques in such areas, we searched for the suitable halophyte species, which tolerates heavy metal contamination.

Cadmium $(\mathrm{Cd})$ is not essential nutrient for higher plants, and the exposure to relatively low Cd concentrations results in serious toxicity (Prasad 1995). The possibility of accumulation of $\mathrm{Cd}^{2+}$ by halophyte species was described by Nedjimi and Daoud (2009).

\section{Material and methods}

\subsection{Cultivation of wetland plants}

For initiation and cultivation of Juncus gerardii Loisel. and Juncus inflexus L. in vitro, modified RH medium (Nitsch $\&$ Nitsch 1969) was used. The seeds were sterilized in $10 \%$ solution of „Savo" $(5 \% \mathrm{NaCl})$ for 5 minutes following with washing 3 times in sterile distilled water and laying on the surface of solid cultivation medium. The seeds germinated 7 days in dark and then they were cultivated under 16-h photoperiod and day/night temperature of $24^{\circ} \mathrm{C}$. After 8 weeks, the seedlings were transferred to the liquid RH medium. The seedlings of halophyte Juncus gerardii were cultivated on the medium with $\mathrm{NaCl}$ in concentration 0,100 and 300 $\mathrm{mM}$ while nonhalophyte Juncus inflexus was cultivated on medium without $\mathrm{NaCl}$. For the induction of heavy metal stress, $100 \mu \mathrm{M} \mathrm{Cd}^{2+}$ was added in the medium in the form of $\mathrm{Cd}\left(\mathrm{NO}_{3}\right)_{2}$ and plants were harvested after 1, 4 and 7 days. 


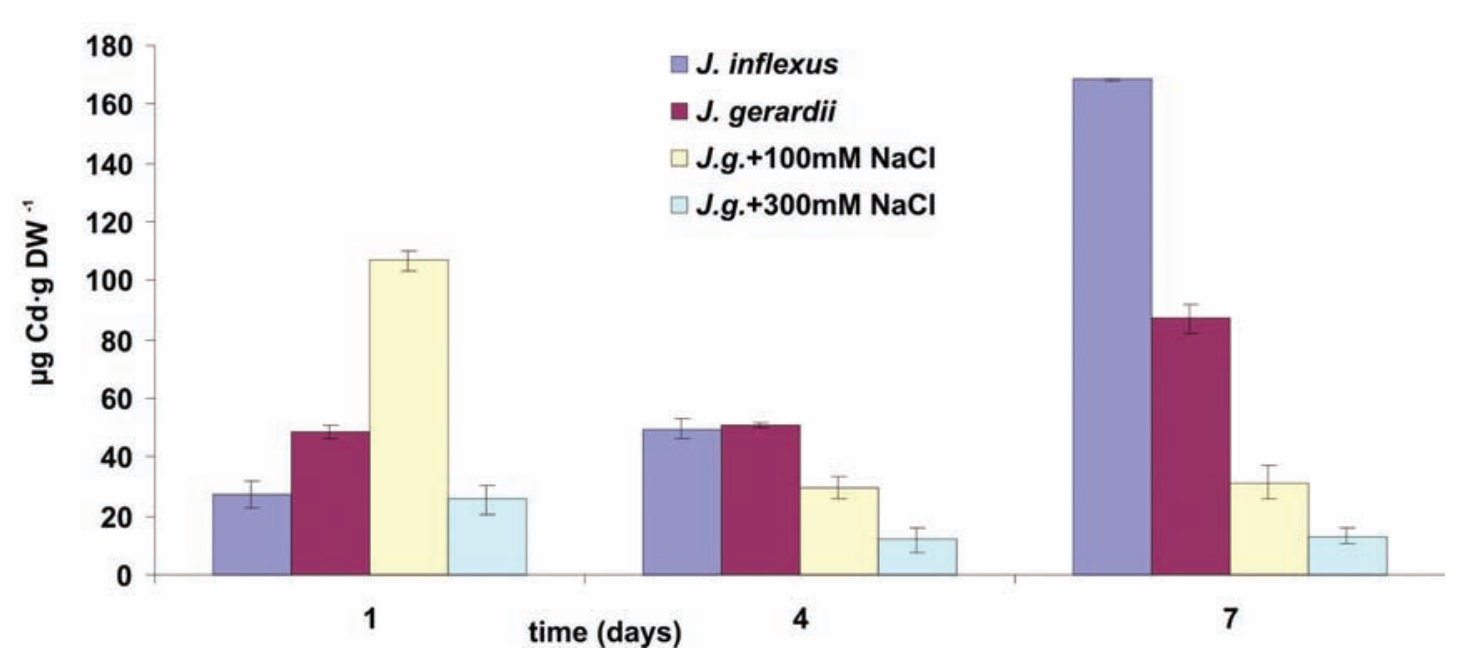

Figure 1. Accumulation of $\mathrm{Cd}^{2+}$ by in vitro cultures of halophyte species Juncus gerardii and nonhalophyte species Juncus inflexus, the starting concentration of $\mathrm{Cd}^{2+}$ was $100 \mu \mathrm{M}$, the halophyte species were cultivated on medium supplemented with $\mathrm{NaCl}$ $(0,100$ and $300 \mathrm{mM})$

\subsection{Plant material analyses}

The frozen plant samples were freeze dried, crushed into a powder and digested overnight in $5 \mathrm{ml}$ of acid mixture of $\mathrm{HClO}_{4}$ and $\mathrm{HNO}_{3}(15 / 85, \mathrm{v} / \mathrm{v})$ in glass digestion tubes. Digestion was carried out in the following way: $3 \mathrm{~h} / 60^{\circ} \mathrm{C}$, $1 \mathrm{~h} / 100^{\circ} \mathrm{C}, 1 \mathrm{~h} / 120^{\circ} \mathrm{C}$ and $3 \mathrm{~h} / 195^{\circ} \mathrm{C}$. After cooling, $2.5 \mathrm{ml}$ of $\mathrm{HCl}(20 \%)$ was added, whirl mixed and warmed to $80^{\circ} \mathrm{C}$ for $1 \mathrm{~h}$. The final volume was made up to $10 \mathrm{ml}$ accurately with double distilled water. Solutions were stored at $4^{\circ} \mathrm{C}$ until the Cd content was analyzed. Cadmium concentrations were determined by atomic absorption spectrophotometer (GBC SensAA Dual Spectrometer).

\section{Results and discussion}

In our experiment we compared the accumulation of $\mathrm{Cd}^{2+}$ by halophyte species Juncus gerardii cultivated on different concentration of $\mathrm{NaCl}(0,100$ and $300 \mathrm{mM})$ and the accumulation of $\mathrm{Cd}^{2+}$ by nonhalophyte specie Juncus inflexus. The amount of $\mathrm{Cd}^{2+}$ accumulated by plants is shown on Figure 1. The highest accumulation of cadmium was observed by nonhalophyte species $J$. inflexus after 7 days of exposure. In the first day, the accumulation of $\mathrm{Cd}^{2+}$ by halophyte was higher then by nonhalophyte, but in following days $\mathrm{Cd}^{2+}$ content in $J$. gerardii increased slowly. The presence of $\mathrm{NaCl}$ in the medium led to reduction of $\mathrm{Cd}$ content in J. gerardii plant tissue. In this case, the highest content of the cadmium was found in the first day and then $\mathrm{Cd}^{2+}$ content decreased.

\section{Acknowledgment}

The authors thank for financial support of COST FA0901 (grant MYES of CR n. OC10028).

\section{References}

Cunningham S. D., Anderson T. A., Schwab A. P. \& Hsu F. C., 1996, Phytoremediation of soils contaminated with organic pollutants, Advances Agronomy 56: 55114.

Nitsch J. P. \& Nitsch C., 1969, Haploid plants from pollen grains, Science 163 (3862): 85-89.

Nedjimi B. \& Daoudb Y., 2009, Cadmium accumulation in Atriplex halimus subsp. schweinfurthii and its influence on growth, proline, root hydraulic conductivity and nutrient uptake, Flora 204: 316-324.

Prasad M. N. V., 1995, Inhibition of maize leaf chlorophylls, carotenoids and gas-exchange functions by cadmium, Phytosynthetica 31: 635-640. 